\title{
CODE MIXING AND SWITCHING ON ‘JUN BINTANG’ CAPTIONS ON THE INSTAGRAM
}

\author{
N.P.E.M. Larasati ${ }^{1}$, D.K. Tantra ${ }^{2}$, I.G.A.L.P. Utami ${ }^{3}$ \\ ${ }^{123}$ English Language Education, Universitas Pendidikan Ganesha, Singaraja \\ e-mail: esamery97@gmail.com ${ }^{1}$, dewatantra@yahoo.com ${ }^{2}$, lokitapurnamika@undiksha.ac.id ${ }^{3}$
}

The phenomenon of mixing and switching languages can easily be found both in real life and on social media, one of which is on Instagram. On Instagram, someone can express themselves in the Instagram caption as Jun Bintang did. Jun Bintang is a multilingual who uses Balinese, Indonesian and English as code mixing and code switching on Instagram social media. Investigating code mixing and code switching as found in the captions of Jun Bintang posts on his Instagram account was the sole research objective. Qualitative research design with descriptive method was applied on code mixing and code switching phenomena. The research objects were focused on Jun Bintang's posts in three languages, they were, Balinese, Indonesian, and English. Data were collected through observations conducted in March to May,2020. Results of data analysis showed that code mixing types frequently used were such types like 1) insertion, 2) congruent lexicalization, and 3) alternation. Whilst, code switching types used were that of 1) inter-sentential, and 2) intra-sentential. Reasons for using code mixing and switching were identified as showing 1) empathy, 2) ease of using first language, 3) purpose of talking specific topic, 4) prestige, 5) interjection, 6) motive, and 7) group identity.

\section{Keywords: Code Mixing; Code Switching; Instagram}

\section{INTRODUCTION}

Language is a means of communication or interaction between humans with one another. Communication is broadly defined as an exchange of ideas, thoughts, feelings and the maintenance of such exchanges (Mujiono et al.,2013; Rahardi, 2001). A communication may be hindered when a speaker is unable to remember a term/word/phrase, but he could remember in other language. This phenomenon is termed as code mixing (Poplack, 1980; Saputro,2013; Spolsky,1998; Wardhaugh, 2002). A code could refer inter-changeably to dialect, accent, speech style, speech level, or even language (Bahous et al., 2014; Larbah, 2013; Mujiono et al., 2013; Sumarsih et al., 2014). Code switching is often alternated when as speaker is not able to express his ideas, thoughts, or feelings by arranging structurally and grammatically in other language (Hoffman,1991; Saputro, 2013; Shafie \& Nayan, 2013).

Socio-linguistically, Indonesia is a multilingual state where people speak two or more languages simultaneously. Wardhaugh (2002) described the situation where people tend to speak using one or two languages in communication usually have the ability to be bilingual or multilingual. Similarly, Spolsky (1998) defined a bilingual as a person who has some functional ability in the second language. Rahardi (2001) added a bilingual as a person who has the ability to master many languages, instead of his/her first language. In Indonesia, there are three types of languages that are mostly used when communicating with others, they are, regional, national language, and international languages. A regional language refers to a language spoken in a province, for examples, Javanese, Balinese, or Sumatranese. A national language refers to a language designated in legislation and spoken as first language in a country, for example, Indonesian. An international language refers to a world language that is spoken and learned internationally by numerous people as a second or a foreign language, for examples, English, French, or German (Luke, 2015; Saputro, 2013).

In the era of information technology, many people speak the language with social media. Varieties of social media sites exist, for examples, Twitter, Facebook, Instagram to mention a few. They have created a new language of their own. Words like Avatar, Bio, Chat, and Follower all have entirely new meanings behind them. Previous research had explored 
code mixing and code switching with different social media platforms. Rinakit (2012) conducted research on code mixing on Twitter. Data were collected from the users' tweets. From all of the tweets written by the Indonesian twitter users, one-hundred tweets were filtered and selected for further analysis. The results indicated five types of code mixing used by the Indonesian twitter users. The code mixing types used by the Twitter users are as follows: Sentence inversion (51\%), unit insertion (39,9\%), idiom and collocation insertion $(4,2 \%)$, unit hybridization $(3,5 \%)$, and reduplication $(1,4 \%)$. They reasoned for using such code mixing types are as follows: quoting somebody else $(6,2 \%)$, showing the users' desire to be understood $(4,5 \%)$, showing an educated person $(31,2 \%)$, expressing habit $(23,2 \%)$, talking something $(11,6 \%)$, expressing mood $(11,6 \%)$, and stressing a certain point $(11,6 \%)$.

Puri (2016) investigated types of code mixing used by Chef Talita Setyadi on Youtube. In collecting data, the purposive sampling method was used. Code mixing can be divided into five, based on their syntactic structure. This research concluded only four types of code mixing existed on the morpheme level with 14 cases, word-level in 8 cases, phrase level in 55 cases, and clause level in 12 cases. The reasons of mixing languages were found as talking about the same things by 72 cases, showing group identity by 6 cases, using repetition for clarification by 6 cases, stressing a certain point by 4 cases, and being emphatic about something by 1 case.

Kalangit (2016) identified the occurrences of code switching on Instagram. In order to get data, an observations were conducted for three months in May to August 2016 to the captions of videos, stories, photos, and also comments written by Instagram users. He selected 120 data that could be categorized as code switching. After analyzing the data, three types of code switching were used by Instagram users on their captions. The type of code switching used are: Inter-sentential by 54 data, Intra-sentential by 50 data, and Emblematic by 16 data. The answer to the second research question indicated that ten reasons for using code mixing found by the researcher, however, the most frequent reason is showing empathic to others by 45 cases.

This research focuses on code mixing and code switching as posted on Jun Bintang Captions on Instagram. Because the phenomenon of code mixing and code switching is not only found in the real world, but also in social media. One of the social media that uses code mixing and code switching is Instagram. Through Instagram social media, they have the opportunity to upload photos or videos, write captions based on their feelings, and enjoy many up-to-date features from Instagram itself. Therefore, it is no stranger to Instagram that social media is popular with Indonesians.

One of the Instagram user is Jun Bintang. His full name is I Made Juniarta or wellknown as Jun Bintang, born in Gianyar-Bali, on June 28, 1975. He is a famous Balinese pop singer and songwriter in Bali. He started his career as a singer, then he tried to write a pop mellow song by himself. Almost all of his songs become favorite songs. He also is acting as an ambassador of Kopi Banyuatis, Prost Beer, and Yamaha Lexi. Being an ambassador for many different products he becomes so popular in the Province of Bali with more than three hundred followers. Uniquely, he is a talented multilingual for using Balinese, Indonesian, and English on the Instagram. He used three different languages on the Instagram to provide evidences of language mix and switch phenomena on Instagram.

\section{RESEARCH METHOD}

The design used was a Qualitative Research (Miles et.al, 2013; Spradley, 1980). The main purpose was directed to analyze code mixing and code switching really used on the Instagram. The research was focused on types of code mixing and code switching in Jun Bintang captions on Instagram. It also studied the reasons behind such language uses.

The research subject was Jun Bintang. He was born in Gianyar, on June 28, 1975. In addition, he was one of the public figures in Bali. He started his career as a solo singer in 2017 , then trying to do a new journey in his life to be a songwriter. Furthermore, he also is an ambassador of Kopi Banyuatis, Prost Beer, and Yamaha Lexi. Being a famous singer and songwriter makes him get more than three hundred followers on his Instagram.

Research objects are data or reliable and valid information about code mixing and code switching types and reasons behind those language uses (Miles et.al, 2013; Spradley, 1980). The captions of Jun Bintang on Instagram account @junbintang_were filtered to be 
the objects of the study. In writing the captions, he used three different languages in one post, they are, Indonesian, Balinese, and English (Amazouz etal., 2018; Bukhari et al., 2015; Myers-Scotton, 2006). Observations were done for eight consecutive days on June 4 to June 12. The data of Jun Bintang's posts were limited in the last three months, starting from March to May. There were 21 posts used more than one language in the captions.

In analyzing the data, two theories from Muysken's (2000) and Hoffman's (1991) were used as theoretical basis. Theoretically, there are three types of code mixing, namely, insertion, alternation, and congruent lexicalization (Muysken, 2000). There are also three code switching types, namely, intra-sentential code switching, inter-sentential code switching, and tag switching (Hoffman,1991).

\section{FINDINGS AND DISCUSSION}

\section{Occurrence of Code Mixing and Switching}

After data analysis, three types of code mixing were identified based on Muysken's (2000) theory. Code mixing types used were those of insertion, alternation, and congruent lexicalization were found. Concurrently, two code switching types were identified based on Hoffman's theory (1991), namely, intra-sentential and inter-sentential but non tag switch in Jun Bintang captions on Instagram. The reasons for such language uses were also disclosed as to talk on specific topics, quote others' speeches, emphasize on somethings, insert interjections, express group's identities, translate into different languages, fulfill certain motives, and show prestige. The occurrences of code mixing and code switching are shown in the following table.

Table 1. Code Mixes and Code Switches

\begin{tabular}{clc}
\hline Language Use & \multicolumn{1}{c}{ Type } & Frequency \\
\hline \multirow{2}{*}{ Code Mixing } & Insertion & 16 \\
& Alternation & 5 \\
& $\begin{array}{l}\text { Congruent } \\
\text { lexicalization } \\
\text { Intra-sentential } \\
\text { code switching }\end{array}$ & 6 \\
Code Switching & Inter-sentential & 11 \\
& code switching & \\
& Tag switching & 0 \\
\hline
\end{tabular}

1) Insertion

Insertion is done by inserting words of the different languages during verbal communications (Hoffman,1991; Muysken,2000). On Jun's verbal encounters as quoted in 'Rahina Jagat' or People's Festival, three languages were used, namely Balinese and Indonesian, and English. Balinese, Indonesian, and English were mixed, for examples, 'tyang' or I, 'dumogi' or hope, 'Hindu sedharma' or my fellows in Hinduism', 'dumogi ring rahina sane becik niki' (Balinese) ,'beri judul' or gave a title, 'merayakan' or celebrated, 'kedamaian hati serta pikiran' or peaceful heart and mind' (Indonesian), 'shooting' (English).

"RAHINA JAGAT -- Tyang beri judul lagu yang langsung tyang ciptakan dilokasi shooting ini untuk tyang persembahkan pada umat Hindu Sedharma yang sedang merayakan Hari Raya Suci Galungan lan Kuningan. Dumogi dengan diiringi lagu ini tercipta ketenangan diri, kedamaian hati serta pikiran. Dumogi ring rahina sane becik niki ngemolihang kerahayuan." (@junbintang_)

2) Alternation

Alternation refers to code use where the speaker mixes a sentence with a phrase (Hoffman,1991; Larbah, 2013; Muysken, 2000). Switching a sentence to a phrase could Jurnal Pendidikan Bahasa Inggris Indonesia | 39 
be identified in Jun Bintang's caption as in the following quote.

"Katanya mau diajarin cara promosin barang di sosmed. Mau niru cewek2 endorse Bali kone. Tumben nganggon Bahasa Indonesia di depan kamera. Jeg agak kaku panake puk.. Kekekee". (@junbintang_)

The speaker switched from a sentence with low speech level in Balinese "Katanya mau diajarin cara promosin barang di sosmed' or I thought you would teach me promote a product in the social media, to Balinese phrases such as 'Mau niru cewek2 endorse Bali kone' or Imitating girls in modern Bali, 'Tumben nganggon Bahasa Indonesia di depan kamera' or Suprisingly you speak Indonesia in front of the camera, .'Jeg agak kaku panake puk' or It's akward. 'Kekekee' a laughter. Baside code switching, the speaker also mixed Balinese, Indonesia and English, for examples, 'endorse' (English), 'cara promosin barang di sosmed' (Indonesian), and 'Tumben nganggon Bahasa Indonesia di depan kamera' and 'Jeg agak kaku panake puk' (Balinese).

\section{3) Congruent Lexicalization}

This type of code mixing happens from a certain language that is made equivalent to other language (Hoffman,1991; Kurnia, 2015; Muysken, 2000). It is mostly used when a speaker wants to say, for example, in Indonesian, but he does not know the word, a word in another language is used. Congruent lexicalization was used in Jun Bintang caption as shown in the following quote.

"Dem Jumah Gen.. Photo ini meceklek pedidi saat saya ngk sengaja ketiduran...yaa..diposting aja. Btw..Yuk..main tebak2an..daripada sibuk pingin keluar rumah. Pertinyiinnyi :: "Kenapa cewek lebih suka mosting photo sama cowoknya di sosmed. Ketimbang cowok yg rada ogah klo ngk terpaksa aja..? Opo alasannya.? Padahal pas putus..capek ngapusnya." (@junbintang_)

In the above caption, 'Dem jumah gen' is a mixed informal sociolect in Balinese 'Medem jumah dogen' or Just slept at home. The word 'diposting' is crongruently lexicalized in English with a prefix di- in the absence of such a word in Balinese or Indonesian. Moreover, 'mosting' has become a derived Balinese word which means lexically 'to post' in English. Some code mixes in irregular Balinese dialect, for examples: 'meceklek pedidi' or clicking by itself, ill-formed 'pertinyiinnyi' or the question, instead of 'pertanyaannya' in Indonesian.

\section{4) Intra-sentential Swicthing}

Intra-sentential code switching is used when a speaker switches from one code to another using a phrase (Hoffman,1991; Ismail, 2015; Muysken, 2000). Such code switching often identified within Jun Bintang caption like in the following example.

\section{"SENTANA"}

Matur Suksma Ping Banget Sampun Ngerauhin tur Nonton Bersama Tyang dan Artis Pendukung Film Niki. Hujan Lebat Tak Menghalangi Kebersamaan Kita. Suksma Majeng ring Pemerintah Kota Denpasar Untuk Tempatnya Yg Keren ..DNA Lumintang. Suksma Info Denpasar Sampun Rauh. Spesial Suksma Majeng ring lbu Walikota @sellyraimantra Beserta Rombongan Yg Selalu Mensupport Para Seniman Bali. Rahayu Bu Gek." (@junbintang_)

The above caption shows an intra-sentential code switching, for example, 'Suksma Majeng ring Pemerintah Kota Denpasar Untuk Tempatnya Yg Keren' or Thank you very much to the Municipality of Denpasar to provide a good place, 'Spesial Suksma Majeng ring Ibu Walikota @sellyraimantra Beserta Rombongan Yg Selalu Mensupport Para Seniman Bali ' or Special thank was due to the Mayor's wife @sellymantra and the group who always supported the Balinese artists, and 'Rahayu Bu Gek' or Be healthy Mrs. Beautiful.

\section{5) Inter-sentential Switching}

The second type of code switching is inter-sentential code switching. Intersentential code switching occurs when a speaker switches from one language to another during communication (Cahyani, et al., 2018; Hoffman, 1991; Milroy \& Muysken, 1995; 
Muysken, 2000). The following caption where inter-sentential code switching could be identified.

"Rest In Peace. Amor ring Acintya. Selamat Jalan Melan Sahabatku. Tenanglah Kamu Disana. Damai Bersama Sang Pencipta๑." (@junbintang_)

The speaker switched from English 'Rest In Peace' to Indonesian 'Selamat Jalan Melan Sahabatku' and Balinese 'Amor Ring Acintya' when he conveyed his grief or condolence to Melan.

\section{6) Tag switching}

Tag switching occurs when a speaker uses a tag, an idiom, an exclamation, and certain phrase in communication and switch it to another language (Gardner-Chloros, 2009; Hoffman,1991; Muysken, 2000). Based on the captions, there was no tag switching code switching found in Jun Bintang's post on Instagram.

\section{Reasons Behind Code Mixing and Switching}

As has been analyzed above, code mixing and code switching were often used in Jun Bintang captions on Instagram. Theoretically, there are eight reasons for using code mixing and code switching, namely: 1) talking about certain topic, 2) quoting somebody else about something, 3) being emphatic, 4) inserting interjection, 5) expressing group identity, 6) limited word or unknown translation, and 8) prestige filling motive (Clark, 1997; García et al., 2018; Hoffman,1991; Luke,2015; Muysken,2000; Myers-Scotton,2006).

When analyzed critically, insertion code mixing in Balinese, Indonesian, and English were used, for examples, 'Rahina Jagat' or People's Holy Festival to show group identity as a believer in Hinduism. Similarly, the words such as 'tyang' or I, 'dumogi' or hope, 'Hindu sedharma' or my fellows in Hinduism', 'dumogi ring rahina sane becik niki' or I hope on today's good day were used to show group identity as Balinese who speak Balinese language. Moreover, the speaker used Indonesian when he had limited words in Balinese such as 'beri judul' or gave a title, 'merayakan' or celebrated, 'kedamaian hati serta pikiran' or peaceful heart and mind. The speaker also used English like 'shooting' for he could not either translated into Balinese orelse he had limited vocabulary in Balinese for 'shooting'.

Alternation code mixing, for example, 'Katanya mau diajarin cara promosin barang di sosmed' or You told me that you would teach me how to promote products in the social media, was used to alternate Balinese with Indonesian to talk about certain topic on product promotion in the social media. The speaker also alternated Balinese with Indonesian and English, for example 'Mau niru cewek2 endorse Bali kone' or I want to follow how the Balinese girls endorsed Bali. Another example of alternation was used to show prestige filling motive, for example, 'Tumben nganggon Bahasa Indonesia di depan kamera. Jeg agak kaku panake puk.. Kekekee' or Rarely you used Indonesian in front of the camera. It looked akward. (a laughter)'.

Congruent lexicalization was used in Jun Bintang caption, for example, 'Dem jumah gen' is a mixed informal sociolect in Balinese to show group identiy as a Balinese who speaks low Balinese comfortably. The word 'diposting' is crongruently lexicalized in English with a prefix di- in the absence of such a word in Balinese or Indonesian. Moreover, 'mosting' has become a derived Balinese word which means lexically 'to post' in English. Some code mixes in low Balinese speech levels, for examples: 'meceklek pedidi' or clicking by itself, ill-formed 'pertinyiinnyi' or the question, instead of 'pertanyaannya' in Indonesian.

Intra-sentential code switching is used when a speaker switches from one code to another using a phrase (Fasold, 1984; Hoffman,1991; Muysken,2000). Such code switching was used to express gratitude emphatically, for example, 'Suksma Majeng ring Pemerintah Kota Denpasar Untuk Tempatnya Yg Keren' or Thank you very much to the Municipality of Denpasar to provide a good place. Similarly, emphatic expression of thank was used, for example, 'Spesial Suksma Majeng ring Ibu Walikota @sellyraimantra Beserta Rombongan Yg Selalu Mensupport Para Seniman Bali 'or Special thank was due to the Mayor's wife @sellymantra and the group who always supported the Balinese 
artists. Moreover, 'Rahayu Bu Gek' or Be healthy Mrs. Beautiful' was used to identify the Mayor's wife belongs to Balinese whose religion is Hinduism.

Inter-sentential code switching was also used to be emphatic in meaning

especially in English, for example, 'Rest in Peace'. Similarly, a Balinese phrase was used in high Balinese, for example, 'Amor ring Acintya' or Rest in peace with Brahma.

Meanwhile, a familiar expression of grief in Indonesia was used to show group identity as close friend, for example, 'Selamat Jalan Melan Sahabatku. Tenanglah Kamu Disana. Damai Bersama Sang Pencipta $\$$ ' or Good bye my friend Melan. Rest in peace beside the Prime Cause.

\section{CONCLUSION AND SUGGESTIONS}

Jun Bintang used code mixing as a communication strategy on the Instagram. He mixed the three languages, namely Balinese, Indonesia, and English. Balinese is his mother tongue, while Indonesian is the national language for the Indonesian citizen including Jun Bintang. English is a foreign language to him. It was noted that Jun Bintang inserted Balinese, Indonesian, and English words, phrases, and sentences within the text entitled 'Rahina Jagat'. He was also observed to alternate Balinese with Indonesian and English when he talked on promoting his products. He frankly admitted that he copied the modern Balinese girls. He mentioned about his first experience in speaking Indonesian in front of the camera. He used an English word 'endorse' in the absence of appropriate Balinese or Indonesian word in his verbal repertoire. Jun Bintang used congruent lexicalization when he did not have knowledge on the words in Balinese, for examples, 'to post' as a verb and 'posting' as a noun. He simply used the English words adding with an Indonesian prefix 'diposting' and, 'mos-ting' prefixed with neither Balinese or Indonesian prefixes.

Aside from code mixing, he used code switching as a communication strategy on the Instagram. He switched from Balinese, to either Indonesia or English. In the text entitled 'Sentana', he used intra-sentential code switching. He thanked the Mayor of Denpasar Municipality in 'Suksma Majeng ring Pemerintah Kota Denpasar Untuk Tempatnya Yg Keren', in a formal way of thanking in Balinese mixed with an appreciation in Indonesian 'untuk tempatnya yang keren'. He was also observed using inter-sentential code switching. He switched from English 'Rest In Peace' to Indonesian 'Selamat Jalan Melan Sahabatku' and Balinese 'Amor Ring Acintya' when he conveyed his grief or condolence to Melan. He was not observed in using tags, for examples, an idiom, an exclamation, and certain phrase in communication.

The reasons in using insertion code mixing were to show group identity as a believer in Hinduism. Moreover, the use of Indonesian was due to limited vocabulary in Balinese for words such as 'beri judul', 'merayakan', 'kedamaian hati serta pikiran'. He directly translated an unknown Balinese word into English as 'shooting'. Alternation code mixing was used as a communication strategy to promote products in the social media. He alternated Balinese with Indonesian to talk about certain topic and to show prestige filling motive. Congruent lexicalization was used to show group identiy as a Balinese who speaks low Balinese comfortably. The word 'diposting' is crongruently lexicalized in English with a prefix di- in the absence of such a word in Balinese or Indonesian. Moreover, 'mosting' has become a derived Balinese word which means lexically 'to post' in English.

Intra-sentential code switching was used is used to express gratitude emphatically, Similarly, emphatic expression of thank was used in Balinese and Indonesia. Balinese was used to identify the Mayor's wife who adheres in Hinduism. Inter-sentential code switching was also used to be emphatic in meaning, especially in English. Similarly, a Balinese expression 'Amor ring Acintya' and an Indonesian expression 'Selamat Jalan Melan Sahabatku. Tenanglah Kamu Disana. Damai Bersama Sang Pencipta' to show group identity.

\section{REFERENCES}

Amazouz, D., Adda-Decker, M., \& Lamel, L. (2018). The French-Algerian code-switching triggered audio corpus (FACST). In LREC 2018 11th edition of the Language Resources and Evaluation Conference, Miyazaki, Japan 
Bahous, R. N., Nabhani, M. B., \& Bacha, N. N. (2014). Code-switching in higher education in a multilingual environment: A Lebanese exploratory study. Language Awareness, 23(4), 353-368.

Cahyani, H., de Courcy, M., \& Barnett, J. (2018). Teachers' code-switching in bilingual classrooms: Exploring pedagogical and sociocultural functions. International Journal of Bilingual Education and Bilingualism, 21(4), 465-479.

Clark, H. (1997). Psychology and Language. London: Harcourt Brace.

Fasold, R. (1984). The Social Linguistic of Society. New York: Basil Blackwell

García, P. B., Leibold, L., Buss, E., Calandruccio, L., \& Rodriguez, B. (2018). Code-switching in highly proficient Spanish/English bilingual adults: Impact on masked word recognition. Journal of Speech, Language, and Hearing Research, 61(9), 2353-2363.

Gardner-Chloros, P. (2009). Code-switching. New York: Cambridge University Press.

Hoffman, C. (1991). An Introduction to Bilingualism. Singapore: Longman.

Ismail, M. A. (2015). The sociolinguistic dimensions of code-switching between Arabic and English by Saudis. International Journal of English Linguistics, 5(5), 99-109.

Kalangit, R. P. (2016). Alih Kode dalam Instagram: Suatu Analisis Sosiolinguistik. Graduating Paper Journal. Manado: Universitas Sam Ratulangi

Kurnia, E. (2015). Description of Using Code Switching and Code Mixing in Conversation by the 9th Semester English Literature Students of State University of Semarang in the Academic Year 2014/2015. Graduating Paper. Semarang: Universitas Negeri Semarang.

Larbah, M. S. (2013). Code switching in ESL classrooms: A study of adult Arabic learners (Master dissertation), Curtin University, Australia.

Luke, J. Y. (2015). The Use of Code-Mixing Among Pamonane in Parata Ndaya ClosedGroup Facebook. Jurnal LINGUA CULTURA, 9(1), 40-46. https://doi.org/10.21512/ Ic.v9i1.760.

Milroy,L.,\&Muysken, P. (1995). One speaker, two languages. Cross-disciplinary perspectives on code-switching. New York, USA: Cambridge University Press.

Miles,M and Huberman,M. (1984). Qualitative data analysis. Beverly Hills,CA: Sage.

Mujiono, M., Poedjosoedarmo, S., Subroto, E., \& Wiratno, T. (2013). Code switching in English as foreign language instruction practiced by the English lecturers at universities. International Journal of Linguistics, 5(2), 46-65.

Muysken, P. (2000). Bilingual Speech: A Typology of Code-Mixing. Cambridge: Cambridge University Press.

Myers-Scotton,C.(2006). Multi voices : An Introduction to Billingualism. Malden MA : Blackwell Publisher

Poplack, S. (1980). Sometimes l'll start a sentence in Spanish y termino en Espanol: Toward a typology of code-switching. Linguistics, 18(7- 8), 581-61.

Puri, N. (2016). Code Mixing Used by Chef Talita Setyadi in Presenting Javanese Caramel Cake Recipe in Junior MasterChef Indonesia Season 1 Episode 11 (Undergraduate Thesis). Universitas Sanata Dharma, Yogyakarta.

Rahardi, K. (2001). Sosiolinguistik Kode dan Alih Kode. Yogyakarta: Pustaka Pelajar

Rinakit, S. (2012) English-Indonesian code-mixing used by Indonesian twitter users as seen Through Their Tweets. Skripsi thesis, Sanata Dharma University

Saputro, A. (2013). The analysis of Indonesian-English code-mixing used in marmutmerah jambu novel. Unpublished Thesis. Salatiga: State Islamic College of Salatiga.

Saville-Troike,M. (1986). The Ethnography of Communication: An Introduction. Oxford: Basil Jurnal Pendidikan Bahasa Inggris Indonesia | 43 
Blackwell Publisher.

Shafie, L., \& Nayan, S. (2013). Languages, code-switching practice and primary functions of Facebook among university students. University of Technology MARA (Perlis), Malaysia (M.A thesis). Retrieved from https://doi.org/10.22158/selt.v1n1p187

Spradley, J. (1980). Participant Observation. New York: Holt, Rinehart and Winston

Spolsky, B. (1998). Sociolinguistics. Oxford : Oxford University Press

Sumarsih, et.al. (2014). Code Switching and Code Mixing in Indonesia: Study in Sociolinguistics. English Language and Literature Studies , 3(6) 77-92

Suwito (1983). Pengantar Awal Sosiolinguistik: Teori dan Problema. Surakarta: Henary Offset Solo.

Wardaugh. (2002). An Introduction to Sociolinguistics. United Kingdom: Blackwell Publishing. 